\title{
Integration of health services, access and utilization by refugees and host populations in West Nile districts, Uganda
}

\author{
Henry Komakech*iD, Lynn Atuyambe and Christopher Garimoi Orach
}

\begin{abstract}
Prolonged civil war and unrest has dominated the short history of South Sudan resulting in the long-term displacement of millions of people since the 1990s. Since December 2013, over one million South Sudanese refugees have fled into Uganda. International and national responses to the refugee influx in the country has been managed through parallel and integrated care and assistance mechanisms. In order to enhance effectiveness and responsiveness of assistance programmes to refugees and host communities in the country, governments and aid agencies should promote the integration of services.
\end{abstract}

Keywords: Uganda, Refugees, Access, Utilization, Healthcare, Integration

\section{Background}

Since 15th December 2013, South Sudan has been going through a civil war. The conflict has resulted to the displacement of over 3.1 million inhabitants. About 2.4 million refugees live in neighbouring countries including; 785,104 in Uganda, 768,125 in Kenya, and 445,441 in Ethiopia [1]. In Uganda, the majority, $71 \%$ of refugees originate from South Sudan. The refugees live in 23 settlements across five districts including; 271,655 in Arua, 257,104 in Adjumani, 151,304 in Moyo, 286,895 in Yumbe and 4623 in Koboko district. About 33\% of the population in these districts are refugees [2]. Globally, this is one of the highest ratio of refugees to host population.

Health services for refugees and host populations are provided based on an integrated approach. The integration process is guided by the Uganda National Integrated Response Plan for Refugees and Host Communities and the Global Strategy for Public Health 2014-2018 of the United Nations High Commission for Refugees (UNHCR). These plans operationalize integration by linking humanitarian and development programming and interventions. Service delivery is aligned with the National Health Policy and Health Sector Development Plan 2015/6-2019/20 [3].

\footnotetext{
* Correspondence: hkomakech@musph.ac.ug

Department of Community Health and Behavioural Sciences, Makerere

University School of Public Health, P. O. Box 7072, Kampala, Uganda
}

Health services integration is promoted and implemented by the Ministry of Health $(\mathrm{MoH})$ through the district health system. Aid agencies support the district health services to enable refugee's access healthcare. Implementation follows a four pronged process including; accreditation and alignment of health facilities and workers by $\mathrm{MoH}$ standards, capacity strengthening, supporting coordination and leadership within $\mathrm{MoH}$ and districts, and realigning aid agencies to support health service delivery [4].

Health services in the west Nile districts are provided by public and private health facilities [4]. In Arua and Adjumani districts, health services are provided through public facilities with support from the UNHCR. While in Moyo, Koboko and Yumbe districts, health service are provided by the UNHCR through aid agencies [5]. Service delivery has expanded through establishment of health facilities by the UNHCR [6]. Access to health facilities (within $5 \mathrm{~km}$ ) varies between 16 and 36\% in Adjumani, $24-68 \%$ in Arua, 16\% in Koboko, 19\% in Moyo and $35-65 \%$ in Yumbe district.

Between January 2014 and June 2017, populations served by health facilities increased from 21 to $36 \%$ in Adjumani, 24-68\% in Arua and 35-65\% in Yumbe districts. Institutional deliveries increased from 63 to $90 \%$ in Adjumani, $40-96 \%$ in Arua and $68-100 \%$ in Yumbe districts between June 2016-July 2017[7]. Outpatient 
Comparison of utilisation of outpatient services June 2016 and July 2017



Fig. 1 Utilization of outpatient services by refugee and host populations during June 2016 and July 2017

consultations increased from 20 to $70 \%$ in Adjumani, $12-77 \%$ in Arua and $50-65 \%$ in Yumbe districts during June 2016-July 2017 [7]. About 22\% (1,557,987) outpatient consultations were made by host communities. [8] (Fig. 1).

\section{Conclusion}

Public health response to population displacements in developing countries remains a challenge. Health service delivery is affected by weak health systems due to inadequate funding, low human resource capacity and a high disease burden. Humanitarian assistance is critical towards improving the wellbeing of the displaced and host populations. It is therefore essential to promote the integration of health services in order to improve equity, effectiveness and efficiency of health services delivery.

\section{Abbreviations}

CSBAG: Civil Society Budget Advocacy Group; JICA: Japan International Cooperation Agency; MoH: Ministry of Health; RMF: Real Medical Foundation; UNHCR: United Nations High Commission for Refugees

\section{Acknowledgements}

Not applicable.

Ethical approval and consent to participate

Not applicable.

\section{Funding}

Not applicable.

\section{Availability of data and materials}

Not applicable.

\section{Authors' contributions}

HK contributed to the conceptualization of the idea and first draft of the manuscript. CGO contributed to the text through advice and development of the manuscript. LA contributed to the review of the manuscript and the text. All authors read and approved the final manuscript.

\section{Consent for publication}

Not applicable.
Competing interests

The authors declare that they have no competing interests.

\section{Publisher's Note}

Springer Nature remains neutral with regard to jurisdictional claims in published maps and institutional affiliations.

Received: 22 October 2018 Accepted: 26 December 2018

Published online: 07 January 2019

\section{References}

1. UNHCR. South Sudan situation, United Nations high Commision for refugees. (2018).

2. UNHCR. Uganda Comprehensive Refugee Response Portal. Kampala: United Nations High Commission for Refugees; 2018a.

3. MoH. Health Sector Development Plan 2015/6-2019/20. M. o. Health. Kampala: Uganda Misntry of Health; 2015.

4. UNHCR. Health and nutrition, Uganda. (2018b).

5. RMF. Wdespread medical needs addressed in Bidibidi refugee settlement, Ream Medical Foundation. (2018).

6. CSBAG. Public financing for the refugee crisis in Uganda. Kampala: Civil Society Budget Advocacy Group; 2018.

7. JICA. Situation Assessment and Needs Identification presentation for Health sector - West Nile Sub-region - 27 Feb 2018. Kampala: Japan International Cooperation agency; 2018.

8. UNHCR. Public health annual report 2017. Kampala: United Nations High Commission for Refugees; 2017.

Ready to submit your research? Choose BMC and benefit from:
- fast, convenient online submission
- thorough peer review by experienced researchers in your field
- rapid publication on acceptance
- support for research data, including large and complex data types
- gold Open Access which fosters wider collaboration and increased citations
- maximum visibility for your research: over 100M website views per year
At BMC, research is always in progress.
Learn more biomedcentral.com/submissions

